\title{
Upaya Kepala Sekolah dalam Menunjang Profesionalisme Guru di MTs NW 02 Kembang Kerang
}

\author{
Nur Anwar Hidayat 1, Mashun 2, Muhammad Munir 3, \\ 1anwarhidayat@gmail.com, ${ }^{2}$ mashunonk@gmail.com, ${ }^{3}$ munir@gmail.com \\ 1, 2, 3 Manajemen Pendidikan Islam, STAI Darul Kamal, Lombok Timur, Indonesia
}

\begin{abstract}
Abstrak
Penelitian ini bertujuan untuk mengetahui Upaya Kepala Sekolah dalam Menunjang Profesionalisme Guru di MTs NW 02 Kembang Kerang. Jenis penelitian yang digunakan adalah kualitatif dengan menggunakan teknik pengumpulan data berupa observasi, wawancara dan dokumentasi dengan menitik beratkan sumber data informan : Kepala sekolah, Wakil Kepala Sekolah, Staf Tata Usaha dan Guru untuk mengokohkan keabsahan data yang diperoleh. Hasil penelitian ini mengungkapkan tiga temuan yaitu : (1) Sudah ada Upaya Kepala Sekolah dalam Menunjang Profesionalisme Guru di MTs NW 02 Kembang Kerang dengan mengirimkan guru untuk mengikuti pelatihan, memberikan surat tugas dan sertifikat pendidikan (2) Sudah ada Langkah-langkah Kepala Sekolah dalam Menunjang Profesionalisme Guru di MTs NW 02 Kembang Kerang dengan membimbing, membina, bekerja sama, dan supervisi dalam Upaya Kepala Sekolah dalam Menunjang Profesionalisme Guru di MTs NW 02 Kembang Kerang (3) sudah ada usaha Kepala Sekolah untuk penyelsaian Kendala-kendala dalam Menunjang Profesionalisme Guru di MTs NW 02 Kembang Kerang.
\end{abstract}

Kata Kunci : Upaya kepala sekolah, profesionalisme guru

\section{Pendahuluan}

Pendidikan adalah setiap usaha, pengaruh, perlindungan, dan bantuan yang diberikan kepada anak tertuju kepada pendewasaan anak itu, atau lebih tepat membantu anak agar cukup, cakap melaksanakan tugas hidupnya sendiri. Pengaruh ini datangnya dari orang dewasa (orang yang diciptakan oleh orang dewasa seperti sekolah, buku, putaran hidup sehari-hari dan sebagainya) dan ditujukan kepada orang yang belum dewasa. ${ }^{1}$

Pendidikan berarti semua perbuatan dan usaha dari generasi tua untuk mengalihkan pengetahuannya, pengalamannya, kecakapannya, serta keterampilannya kepada generasi muda sebagai usaha menyiapkannya agar dapat memenuhi fungsi hidupnya baik jasmaniah maupun rohaniah. ${ }^{2}$ Pendidikan sebagai salah satu sektor yang paling penting dalam pembangunan nasional, dijadikan

${ }^{1}$ Muhammad Kristiawan, Manajemen Pendidikan (Yogyakarta: CV Budi Utama, 2017), 2.

2 Tobroni, Pendidikan Islam (Jakarta: Mitra Wacana Media, 2015), 19 
andalan utama untuk berfungsi semaksimal mungkin dalam upaya meningkatkan kualitas hidup manusia Indonesia, di mana iman dan takwa kepada Tuhan yang Maha Esa menjadi sumber motivasi kehidupan segala bidang. ${ }^{3}$

Menurut perspektif kebijakan pendidikan nasional terdapat tujuh peran utama kepala sekolah yaitu, sebagai edukator (pendidik), manajer, administrator, supervisor, leader (pemimpin), pencipta iklim kerja, dan wirausahawan. ${ }^{4}$ Kepala sekolah harus mampu menggerakkan guru agar profesionalnya meningkat, karena guru merupakan ujung tombak untuk mewujudkan manusia yang berkualitas. Guru akan bekerja secara maksimum apabila didukung oleh beberapa faktor diantaranya adalah kepemimpinan kepala sekolah. Pentingnya pemimpin dan kepemimpinan ini perlu dipahami dan dihayati oleh setiap umat Islam di negeri yang mayoritas warganya beragama Islam ini, meskipun Indonesia bukanlah negara Islam. Allah SWT telah memberi tahu kepada manusia, tentang pentingnya kepemimpinan dalam islam, sebagaimana yang berbunyi dalam Al-Quran Surah Al Baqarah ayat 30, Ingatlah ketika Tuhanmu berfirman kepada para Malaikat: "Sesungguhnya Aku hendak menjadikan seorang khalifah di muka bumi". Mereka berkata: "Mengapa Engkau hendak menjadikan (khalifah) di bumi itu orang yang akan membuat kerusakan padanya dan menumpahkan darah, padahal kami senantiasa bertasbih dengan memuji Engkau dan mensucikan Engkau?" Tuhan berfirman: "Sesungguhnya Aku mengetahui apa yang tidak kamu ketahui".

Beberapa permasalahan yang ditemui dalam sekolah MTs NW 02 Kembang Kerang merupakan sekolah swasta yang mempunyai kemampuan dalam menunjang profesionalisme guru, namun berdasarkan observasawal yang telah dilakukan peneliti didapatkan keterangan dari kepala sekolah bahwa kinerja guru di MTs NW 02 Kembang Kerang belumlah sepenuhnya baik. Peran kepala sekolah sebagai supervisor telah berusaha menunjang profesionalisme guru melalui perencanaan program supervisi, pelaksanaan dan menindaklanjuti hasil evaluasi supervisi, namun sampai sekarang masih ada guru yang belum faham tentang tugas-tugas yang wajib dipenuhi oleh seorang guru misalnya dalam kelengkapan perangkat pembelajaran, kedisiplinan yang masih perlu diterapkan, adanya guru yang belum menguasai materi pelajaran secara baik, masih ada beberapa guru yang memiliki banyak tugas tambahan, masih ada guru yang belum menguasai IT, masih ada beberapa guru yang kurang inovasi dan kreativitas dalam pelayanan pembelajaran dan kurangnya sarana dan prasarana untuk penunjang kinerja guru.

${ }^{3}$ Fuad Ikhsan, Dasar-Dasar Pendidikan (Jakarta: PT Rineka Cipta, 2003), 4.

4 Agustinus Hermino, Kepemimpinan Pendidikan di Era Globalisasi. (Yogyakarta : Pustaka Pelajar, 2014), 142. 


\section{Kajian Pustaka}

Guru adalah seseorang yang mengajar atau mendidik khususnya di sekolah (lembaga formal). Guru merupakan orang yang bertanggung jawab terhadap perkembangan peserta didik dengan mengupayakan perkembangan seluruh potensinya, baik potensi kognitif (knowledge), potensi afektif, maupun potensi psikomotorik. ${ }^{5}$

Guru adalah salah satu di antara faktor pendidikan yang memiliki peranan yang paling strategis, sebab gurulah sebetulnya yang paling menentukan di dalam terjadinya proses belajar mengajar. Peran guru sangat vital bagi pembentukan kepribadian, cita-cita, dan visi misi yang menjadi impian hidup anak didiknya di masa depan. Di balik kesuksesan murid, selalu ada guru profesional yang memberikan inspirasi dan motivasi besar pada dirinya sebagai sumber stamina dan energi untuk selalu belajar dan bergerak mengejar ketertinggalan, menggapai kemajuan, menorehkan prestasi spektakuler dalam mencapai kemajuan suatu bangsa. ${ }^{6}$

Menurut mulyasa, menjelaskan peran dan fungsi guru berpengaruh terhadap pelaksanaan pendidikan sekolah sebagai berikut;

1. Sebagai pendidik dan pengajar, bahwa setiap guru harus memiliki kestabilan emosi, ingin memajukan peserta didik, bersikap realitas, jujur, dan terbuka, serta peka terhadap perkembangan, terutama inovasi pendidikan.

2. Sebagai anggota masyarakat, bahwa setiap guru harus pandai bergaul dengan masyarakat.

3. Sebagai pemimpin, bahwa setiap guru adalah pemimpin, yang harus memiliki kepribadian, menguasai ilmi kepemimpinan, prinsip hubungan antar manusia, teknik berkomunikasi, serta menguasai berbagai aspek kegiatan organisasi sekolah.

4. Sebagai administrator, bahwa setiap guru akan dihadapkan pada berbagai tugas administrasi yang harus dikerjakan di sekolah, sehingga harus memiliki pribadi yang jujur, teliti, rajin, serta memahami strategi dan manajemen pendidikan.

${ }^{5}$ Aminatul Zahroh, Membangun kualitas pembelajaran melalui dimensi profesionalisme guru (Bandung: Yrama Widya, 2015), 02.

${ }^{6}$ Hamni Fadlilah Nasution, "Urgensi profesionalisme guru di pendidikan sekolah dasar" Institut Agama Islam Negeri Padangsidimpuan, Vol.1, No.01, 2017 
5. Sebagai pengelola pembelajaran, bahwa setiap guru harus mampu menguasai berbagai metode pembelajaran dan memahami situasi belajar mengajar. ${ }^{7}$

\section{Tugas dan Tanggung Jawab Guru}

Tugas guru secara umum adalah mendidik. Dalam operasionalisasinya, mendidik adalah rangkaian proses mengajar, memberikan dorongan, memuji, menghukum, membentuk contoh dan membisakan. Tugas khusus seorang guru antara lain sebagai berikut:

1. Sebagai pengajar (Intruksional)

Sebagai pengajar (intruksional), guru bertugas merencanakan progam pengajaran, melaksanakan progam yang telah disusun dan melaksanakan penilaian setelah progam itu dilaksanakan.

\section{Sebagai pendidik (Edukator)}

Sebagai pendidik (edukator) guru bertugas mengarahkan peserta didik pada tingkat kedewasaan yang berkepribadian sempurna.

3. Sebagai pemimpin (Managerial)/Leader

Sebagai pemimpin, guru bertugas memimpin dan mengendalikan diri sendiri,peserta didik dan masyarakat yang terkait, menyangkut upaya pengarahan, pengawasan, pengorganisasian, pengontrolan, partisipasi atas progam yang dilakukan. ${ }^{8}$

Guru memiliki tugas dan tanggung jawab yang sama yakni: a) Membuat program pembelajaran atau tahunan; b) Membuat satuan dan rencana pembelajaran; c) Melaksanakan kegiatan pembelajaran; d) mengadakan pengembangan setiap bidang pembelajaran yang menjadi tanggung jawabnya; e) Meneliti daftar peserta didik sebelum memulai jam pelajaran; f) Membuat dan menyusun lembar kerja untuk mata pelajaran yang memerlukannya; g) Membuat catatan tentang kemajuan hasil belajar masing-masing peserta didik; h) Membersihkan ruang tempat praktik, laboratorium, dan sebagainnya dan i)Memeriksa apakah peserta didik sudah paham benar akan cara penggunaan masing-masing peralatanya itu untuk menghindari terjadinya kerusakan dan kecelakaan peran kepala madrasah untuk menyediakan fasilitas pembelajaran, melakukan pembinaan pertumbuhan jabatan guru, dan

${ }^{7}$ Mesiono, Inovasi Pendidikan, (Medan: Perdana Publishing, 2012), 157-158

${ }^{8}$ Mudlofir, Pendidikan Profesional, (Jakarta: PT Raja Grofindo, 2015), 102 
dukungan profesionalitas lainnya menjadi suatu kekuatan tersendiri bagi guru melaksanakan tugas profesionalnya. ${ }^{9}$

\section{Pengertian Profesionalisme Guru}

Profesionalisme adalah pekerjaan atau kegiatan yang dilakukan oleh seseorang dan menjadi sumber penghasilan kehidupan yang memerlukan keahlian,kemahiran, atau kecakapan yang memenuhi standar mutu atau norma tertentu serta memerlukan pendidikan. ${ }^{10}$ Profesionalisme guru adalah kualitas guru yang memiliki kemampuan dan keahlian khusus dalam bidang keguruan sehingga ia mampu melakukan tugas dan fungsinya sebagai guru dengan baik yang didukung adanya kemampuan maksimal.11

Profesionalisme guru dapat diwujudkan melalui pemberdayaan potensi dan prestasi guru. Seorang guru disebut sebagai guru profesional karena kemampuannya dalam mewujudkan kinerja profesi guru secara utuh. Dengan demikian sifat utama dari seorang guru profesional adalah kemampuannya dalam mewujudkan kinerja profesional yang sebaikbaiknya dalam mencapai tujuan pendidikan. Sifat-sifat ini mencakup ciriciri kepribadian guru dan penguasaan keterampilan teknis keguruan.

Dengan kata lain seorang guru hendaknya memiliki kompetensi yang mantap.Kompetensi merupakan seperangkat pengetahuan, keterampilan, prilaku yang harus dimiliki, dihayati, dikuasai, dan diaktualisasikan oleh guru dalam melaksanakan tugas keprofesionalan.38 Peraturan pemerintah nomor 19 Tahun 2015 tentang standar nasional pendidikan menyebutkan empat komponen standar kompetensi yang harus dimiliki guru yaitu: (1) Kompetensi kepribadian ; (2) Kompetensi pedagogik ; (3) Kompentensi profesional; (4) Kompetensi

sosial.

\section{Metode penelitian}

Penelitian ini merupakan penelitian kualitatif dengan pendekatan fenomenologis dimana peneliti masuk dalam proses yang diteliti. Teknik kualitatif dipakai sebagai pendekatan dalam penelitian ini, karena teknik ini untuk memahami realitas rasional sebagai realitas subjektif khususnya warga sekolah.

${ }^{9}$ Kompri, Standardisasi Kompetensi Kepala Sekolah, (Jakarta: Kencana, 2017), 118

10 Yusutria, "Profesinalisme Guru Dalam Meningkatkan Kualitas Sumber Daya Manusia" STKIP PGRI Sumatera Barat, Vol 2, No. 1, 2017.

11 Aminatul Zahroh, Membangun kualitas pembelajaran melalui dimensi profesionalisme guru (Bandung: Yrama Widya, 2015),Hal.43 
Proses observasi dan wawancara mendalam bersifat sangat utama dalam pengumpulan data.

Tempat penelitian ini adalah di MTs NW 02 Kembang Kerang. Penelitian ini dilaksanakan berdasarkan penyesuaian topik yang dipilih oleh peneliti. Alasan peneliti memilih lokasi di MTs NW 02 Kembang Kerang ini karena ketika melaksanakan tugas, peneliti menemukan masalah yang terdapat di lembaga ini, dan menurut peneliti masalah ini perlu dikaji dan dianalisis. Dengan pemilihan lokasi ini, diharapkan menemukan hal- hal yang bermakna dan baru.

Tahap-tahap dalam pengumpulan data dalam penelitian ini menckup tahap pengamatan lapangan, setelah mengamati fenomena yang terjadi peneliti mencatat langsung fenomena yang terjadi yang terkait dengan upaya peningkatan profesionalisme guru yang dilakukan oleh kepala sekolah di MTs NW 02 Kembang Kerang. Wawancara ini ada beberapa yang akan dijadikan informan, diantaranya adalah Kepala Sekolah (Bapak Jamaluddin, S.P.d.I) selaku pemimpin, Wakil Kepala Sekolah (Sahabuddin, S.Pd.I), Staf Tata Usaha dan guru-guru yang mengajar di MTs NW 02 Kembang Kerang. Tahapan dokumentasi ini digunakan oleh peneliti untuk memperoleh data mengenai profil sekolah diantaranya : sejarah berdirinya sekolah, visi, misi dan tujuan, sarana dan prasarana dan juga tentang Upaya Kepala Sekolah dalam Menunjang Profesioanlisme guru di MTs NW 02 Kembang Kerang.

\section{Hasil dan Pembahasan}

\section{A. Upaya Kepala Sekolah dalam Menunjang Profesionalisme Guru}

Hasil wawancara peneliti dengan Kepala Madrasah MTs NW 02 Kembang Kerang Bapak Jamaluddin, S.Pd.I mengenai Upaya Kepala Sekolah dalam Menunjang profesionalisme guru adalah sebagai berikut:

"Beliau mengatakan upaya yang dilakukan untuk menunjang profesionalisme guru yaitu, memberdayakan kompetensi yang dimiliki oleh guru, KKG, mengadakan pelatihan, diklat, penataran dan lokakarya perlu dilaksanakan oleh guru dengan diikuti usaha tindak lanjut untuk menerapkan hasil-hasil pelatihan. Selanjutnya yaitu dilakukannya program pembinaan secara khusus seperti sertifkasi, dalam sertifikasi tercermin adanya suatu uji kelayakan dan kepatutan yang harus dijalani seorang guru, terhadap kriteria-kriteria yang secara ideal telah ditetapkan."12

${ }^{12}$ Hasil wawancara dengan Kepala Madrasah (Jamaluddin, S.Pd.I) Tanggal 10 Mei 2020 pukul 09.00 WITA. 
Penjelasan yang dipaparkan oleh informan di atas terkait dengan upaya kepala sekolah dalam menunjang profesionalisme guru yang dilakukan kepala sekolah baik itu dari memberdayakan kompetensi yang dimiliki oleh guru, KKG, mengadakan pelatihan, diklat, penataran dan lokakarya yang mana pelatihan ini merupakan salah satu teknik pembinaan untuk menambah wawasan/ pengetahuan guru- guru dan memberikan kesempatan kepada guru-guru untuk meningkatkan pengetahuan dan keterampilannya dengan belajar ke jenjang penddikan yang lebih tinggi. Pelatihan ini merupakan suatu usaha untuk mengembangkan kemampuan berfikir dan bekerja bersama-sama baik mengenai masalah teoritis maupun praktis, dengan maksud untuk meningkatkan mutu hidup pada umumnya serta mutu dalam hal pekerjaan. Dengan adanya pelaitahan ini, guru diharapkan akan memperoleh pengalaman baru dan dapat menumbuhkan daya kreatifitas serta dapat memproduksi hasil yang berguna dari proses belajar mengajar.

Hasil wawancara peneliti dengan Wakil Kepala Sekolah Bapak Sahabuddin, S.Pd.I (Bidang Kurikulum) mengenai upaya Kepala Sekolah dalam Menunjang profesionalisme guru adalah sebagai berikut:

“Upaya yang dilakukan kepala sekolah dalam menunjang profesionalisme guru diantaranya yaitu kepala sekolah melakukan upaya pemberdayaan terhadap kompetensi guru ataupun Kelompok Kerja Guru (KKG) yang dapat dilakukan dalam penyamaan persepsi dan komitmen untuk peningkatan mutu pembelajaran ataupun pemecahan masalah dalam pembelajaran, melalui organisasi musyawarah guru mata pelajaran (MGMP), tujuan dilakukannya MGMP ini untuk meningkatkan kinerja guru sebagai perilaku perubahan pembelajaran yang dilakukan didalam kelas."13

Sejalan dengan apa yang dijelaskan oleh kepala sekolah, informan menjelaskan bahwa upaya kepala sekolah memiliki peranan yang sangat besar terhadap peningkatan keprofesionalismeannya, Upaya kepala sekolah

${ }^{13}$ Hasil wawancara dengan wakil Kepala Madrasah I (Bidang Kurikulum) (Sahabuddin, S.Pd.I). Tanggal 13 Mei 2020 pukul 09.00 WITA. 
dalam menunjang profesionalisme guru di Madrasah Tsanawiyah NW 02 Kembang Kerang cukup baik, dikarenakan penjelasan dari informan di atas yang telah mengikuti program-program diantaranya Kelompok Kerja Guru (KKG), Musyawarah Guru Mata Pelajaran (MGMP), kegiatan diklat, penataran serta lokakarya yang sebagaimana mestinya dilakukan untuk meningkatkan dan menunjang profesionalisme guru.

Hasil wawancara peneliti dengan Staff Tata Usaha Abdul hafiz mengenai upaya kepala sekolah dalam meningkatkan profesionalisme guru sebagai berikut:

"Kepala sekolah mengatakan upaya yang dilakukan dalam menunjang profesionalisme guru yaitu mengikut sertakan guru-guru dalam Workshop dan seminar tentang profesionalisme guru, selanjutnya diadakannya pelatihan-pelatihan atau diklat."14

informan menjelaskan bahwa upaya kepala sekolah dalam menunjang profesionalisme guru dengan mengadakan pelatihan, Pelatihan ini merupakan proses pengembangan dan pengarahan pengetahuan dan keterampilan sikap dan perilaku yang dapat direncanakan untuk dapat memenuhi kebutuhan baik saat ini maupun masa yang akan datang. Mengikut musyawarah guru mata pelajaran (MGMP) dan evaluasi yang dilakukan oleh kepala sekolah guna mengetahui sejauhmana tiap-tiap guru bidang studi memahami dan menguasai mata pelajaran yang diampunya serta memberikan mereka tugas untuk membuat karya ilmiah tentang pendidikan dan tindakan kelas.

Hasil wawancara peneliti dengan Guru mengenai upaya kepala sekolah dalam menunjang profesionalisme guru sebagai berikut:

“Upaya yang dilakukan oleh kepala sekolah dalam menunjang profesionalisme guru salah satunya yaitu dengan pelatihan (diklat), pembinaan, pertemuan individu ataupun menciptakan nuansa kebersamaan dan kekeluargaan, pengiriman guru dalam kegiatan akademik berupa penataran, seminar, kelompok kerja guru (KKG), musyawarah guru mata pelajaran (MGMP)."15

${ }^{14}$ Hasil wawancara dengan Staf Tata Usaha (Abdul Hafiz). Tanggal 15 Mei 2020 pukul 10.00 WITA.

${ }^{15}$ Hasil wawancara dengan Guru. Tanggal 17 Mei 2020 pukul 09.00 WITA. 
Berdasarkan paparan hasil wawancara dapat disimpulkan bahwa upaya kepala sekolah dalam menunjang profesionalisme guru yaitu memberdayakan kompetensi yang dimilki oleh guru, Kelompok Kerja Guru (KKG), yang mana tujuan dari diadakannya Kelompok Kerja Guru untuk meningkatkan kompetensi peserta kelompok kerja dalam melaksanakan proses belajar mengajar dengan berkelanjutan. Selain itu dengan diadakannya Kelompok Kerja Guru, guru juga dapat meningkatkan kualifikasinya sebagai guru dan persiapan guru dalam menghadapi proses sertifikasi.

Selanjutnya melalui Musyawarah Guru Mata Pelajaran dapat meningkatkan profesionalisme guru dalam melaksanakan pembelajaran yang bermutu sesuai dengan kebutuhan peserta didik. Musyawarah Guru Mata Pelajaran (MGMP), yang berfungsi sebagai wadah maupun sarana komunikasi, konsultasi, dan tukar pengalaman. tujuan dilakukannya MGMP ini untuk meningkatkan kinerja guru sebagai perilaku perubahan pembelajaran yang dilakukan didalam kelas. Selanjutnya mengadakan pelatihan, yang mana pelatihan ini merupakan salah satu teknik pembinaan untuk menambah wawasan/ pengetahuan guru-guru dan memberikan kesempatan kepada guruguru untuk meningkatkan pengetahuan dan keterampilannya dengan belajar ke jenjang penddikan yang lebih tinggi. Kegiatan pelatihan (Diklat) perlu dilaksanakan oleh guru dengan diikuti usaha tindak lanjut untuk menerapkan hasil-hasil pelatihan.

Kesimpulan Upaya kepala sekolah MTs NW 02 Kembang Kembang dalam Peningkatan dan menunjang Profesionalisme Guru dengan a) Pembinaan kedisiplinan kerja, b) Pemberian motivasi dan penghargaan, c) Menjalin hubungan kerja yang baik sehingga merasa memiliki dan dimiliki, d) Pemberian dan pemenuhan kesejahteraan dan jaminan keselamatan kerja, e) kebutuhan akan aktualisasi dan pengembangan diri, f) Mengikuti pelatihan kependidikan, ikut serta MGMP, seminar, workshop, pembinaan profesi baik yang 
dilaksanakan dari pihak sekolah maupun dari luar sekolah dan pendidikan lanjut, g) Program sertifikasi guru untuk menunjang kinerja guru yang baik.

\section{B. Langkah-langkah Kepala Sekolah dalam Menunjang Profesionalisme Guru}

Hasil wawancara peneliti dengan Kepala MTs NW 02 Kembang Kerang mengenai langkah-langkah kepala sekolah dalam menunjang profesionalisme guru beliau memberikan jawaban sebagai berikut:

"Langkah-langkah yang dapat dilakukan yaitu dengan meningkatkan pengetahuan guru dengan mendelegasikan guru pada kegiatan pendidikan yang bertujuan untuk meningkatkan profesionalismeannya baik dalam bentuk seminar maupun penataran, meningkatkan kreatifitas guru yaitu dengan merangsang dan membangkitkan semangat guru dalam mengajar. Memberikan pengawasan dan bimbingan serta bantuan kepada guru, Menyediakan media serta kelengkapan pusat sumber belajar, bekerjasama untuk mengembangkan model pembelajaran, berusaha membina kerjasama baik dengan para guru, dan staf pegawai, meningkatkan kedisiplinan guruguru termasuk untuk guru berpartsipasi dalam setiap kegiatan sekolah, dan pemberian penghargaan terhadap guru maupun pegawai yang berprestasi." 16

Berdasarkan paparan hasil wawancara dapat disimpulkan bahwa langkah- langkah yang dilakukan kepala sekolah dalam menunjang profesionalisme guru yaitu meningkatkan pengetahuan guru, meningkatkan kreatifitas guru yaitu dengan merangsang dan membangkitkan semangat guru dalam mengajar, memberikan pengawasan dan bimbingan serta bantuan kepada guru, menyediakan media serta kelengkapan pusat sumber belajar, bekerjasama untuk mengembangkan model pembelajaran, berusaha membina kerjasama baik dengan para guru, dan staf pegawai.

Hasil wawancara peneliti dengan Wakil Kepala Madrasah (Bidang Kurikulum) MTs NW 02 Kembang Kerang mengenai langkahlangkah yang dilakukan kepala sekolah dalam menunjang profesionalisme guru beliau memberikan jawaban sebagai berikut:

16 Hasil wawancara dengan Kepala Madrasah (Jamaluddin, S.Pd.I) Tanggal 10 Mei 2020 pukul 09.00 WITA. 
"Membantu guru memahami, memilih dan merumuskan tujuan pendidikan, memberikan pengakuan atau penghargaan terhadap prestasi kerja guru secara layak, mendelegasikan tanggung jawab dan kewenangan kerja kepada guru untuk mengelola proses belajar mengajar dengan memberikan kebebasan dalam perencanaan, pelaksanaan dan evaluasi hasil belajar. membantu memberikan kemudahan kepada guru dalam proses pengajuan kenaikan pangkatnya sesuai dengan peraturan yang berlaku, membuat kebijakan sekolah dalam pembagian tugas guru, baik beban tugas mengajar, beban administrasi guru maupun beban tugas tambahan lainnya harus disesuaikan kemampuan guru itu sendiri dan masih banyak lagi langkah-langkah yang dapat dilakukan."17

Langkah-langkah yang dilakukan kepala sekolah di Madrasah Tsanawiyah NW 02 Kembang Kerang berjalan cukup baik, karena kepala sekolah mendelegasikan tanggung jawab dan kewenangan kerja kepada guru untuk mengelola proses belajar mengajar dengan memberikan kebebasan dalam perencanaan, pelaksanaan dan evaluasi hasil belajar. Kemampuan membantu memberikan kemudahan kepada guru dalam proses pengajuan kenaikan pangkatnya sesuai dengan peraturan yang berlaku, membuat kebijakan sekolah dalam pembagian tugas guru, baik beban tugas mengajar, beban administrasi guru maupun beban tugas tambahan.

Penjelasan tersebut diperjelas kembali oleh Abdul Hafiz selaku Staf tata usaha mengenai langkah-langkah kepala sekolah dalam menunjang profesionalisme guru, beliau mengatakan:

"Mendelegasikan tanggung jawab dan kewenangan kerja kepada guru untuk mengelola proses belajar mengajar dengan memberikan kebebasan dalam perencanaan, pelaksanaan dan evaluasi hasil belajar. Melaksanakan teknik supervisi yang tepat sesuai dengan kemampuannya dan sesuai dengan keinginan guru-guru secara berkesinambungan dalam upaya memperbaiki dan meningkatkan kemampuan guru dalam proses pembelajaran, mengupayakan selalu meningkatkan kesejahteraannya yang dapat diterima guru serta dalam memberikan pelayan sebaik-baiknya,

17 Hasil wawancara dengan wakil Kepala Madrasah I (Bidang Kurikulum) (Sahabuddin, S.Pd.I). Tanggal 13 Mei 2020 pukul 09.00 WITA. 
menciptakan hubungan kerja yang sehat dan menyenangkan di lingkungan sekolah, terutama di dalam kelas."18

Penjelasan yang di uraikan oleh Staf tata usaha memiliki keterkaitan dengan apa yang disampaikan oleh guru mengenai langkah-langkah kepala sekolah dalam menunjang profesionalisme guru di Madrasah Tsanawiyah NW 02 Kembang Kerang agar berjalan secara efektif dan efisisen.

Hasil wawancara peneliti dengan Guru mengenai Langkah- langkah Kepala Sekolah dalam menunjang profesionalisme guru adalah sebagai berikut:

“Memberikan tempat kerja yang menyenangkan, alat pelajaran yang cukup, tempat beristrahat di sekolah yang nyaman, kebersihan dan keindahan sekolah, memberikan peluang kepada guru untuk tumbuh dalam meningkatkan pengetahuan, meningkatkan keahlian mengajar, dan memperoleh keterampilan yang baru, memperhatikan peningkatan status guru dengan memenuhi kelengkapan status berupa perlengkapan yang mendukung kedudukan kerja guru."19

Dari hasil wawancara di atas menunjukkan bahwa langkah-langkah yang dilakukan kepala sekolah dalam menunjang profesonalisme guru yaitu banyak

yang dilakukan terutama membantu guru memahami, memilih dan merumuskan tujuan pendidikan, memberikan pengakuan atau penghargaan terhadap prestasi kerja guru secara layak, mendelegasikan tanggung jawab dan kewenangan kerja kepada guru untuk mengelola proses belajar mengajar dengan memberikan kebebasan dalam perencanaan, meningkatkan pengetahuan guru dengan mendelegasikan guru pada kegiatan pendidikan yang bertujuan untuk meningkatkan profesionalismeannya baik dalam bentuk seminar maupun penataran, meningkatkan kreatifitas guru yaitu dengan merangsang dan membangkitkan semangat guru dalam mengajar.

\footnotetext{
${ }^{18}$ Hasil wawancara dengan Staf Tata Usaha (Abdul Hafiz). Tanggal 15 Mei 2020 pukul 10.00 WITA.

${ }^{19}$ Hasil wawancara dengan Guru. Tanggal 17 Mei 2020 pukul 09.00 WITA.
} 
Kesimpulan Langkah-langkah Kepala Sekolah dalam Menunjang Profesionalisme Guru di MTs NW 02 Kembang Kerang adalah melalui pembinaan-pembinaan terhadap guru berupa pembinaan peningkatan kemampuan, artinya untuk melakukan kegiatan pendidikan secara efektif dan efisien, para guru harus mempunyai kemampuan yang memadai dalam proses pembelajaran. membina guru dalam kegiatan proses pembelajaran, membimbing dalam menyiapkan perangkat pembelajaran, melakukan pembinaan proses pembelajaran sebagaimana yang direncanakan. memotivasi para guru dengan cara menciptakan situasi yang harmonis dan saling bekerjasama sesama guru, berusaha memenuhi perlengkapan yang diperlukan guru dalam melaksanakan tugasnya, memberikan penghargaan dan hukuman. mengirim para guru untuk mengikuti seminar-seminar dan pelatihanpelatihan, mendatangkan para tutor ke sekolah, memberikan kesempatan kepada para guru untuk melanjutkan pendidikannya, menempatkan guru pada proporsi yang sesuai dengan bidangnya, dan mengadakan rapat guru setiap semester untuk mengevaluasi kinerja guru sekaligus memberikan pengarahan terhadap sasaran yang belum tercapai.

\section{Kendala-Kendala Kepala Sekolah dalam Menunjang Profesionalisme Guru}

Hasil wawancara peneliti dengan kepala MTs NW 02 Kembang Kerang mengenai kendala-kendala kepala sekolah dalam menunjang profesonalisme guru, beliau memberikan jawaban sebagai berikut:

“Setiap pekerjaan yang dilaksanakan tidak terlepas dari yang namanya kendala ataupun hambatan, termasuk dalam menjalankan keprofesionalismean seorang guru. Kendala yang ada seperti sarana prasarana yang kurang memadai, pembiayaan yang kurang dan faktor dari dalam diri guru itu sendiri yang enggan mengembangkan potensinya. Semakin cepatnya perkembangan teknologi sehingga menuntut guru lebih proaktif terhadap perkembangan tersebut." 20

20 Hasil wawancara dengan Kepala Madrasah (Jamaluddin, S.Pd.I) Tanggal 10 Mei 2020 pukul 09.00 WITA. 
Berdasarkan paparan hasil wawancara dapat disimpulkan bahwa mengenai kendala-kendala kepala sekolah dalam menunjang profesionalisme guru diantaranya sarana prasarana yang kurang memadai, Lemahnya motivasi dalam meningkatkan kemampuan mereka beralasan karena sibuknya waktu dalam melakukan pengajaran dan rumah tangga. Untuk mengatasi hal tersebut, maka upaya yang dilakukan kepala sekolah adalah mendorong dan memotivasi guru untuk aktif dalam penngembangan diri dan pelatihan.

Hasil wawancara peneliti dengan Wakil Kepala Madrasah I (Bidang Kurikulum) mengenai kendala-kendala dalam menunjang profesionalisme guru di Madrasah Tsanawiyah NW 02 Kembang Kerang, beliau memberikan jawaban sebagai berikut:

"Faktor penghambat ataupun kendala dalam menunjang profesionalisme guru yaitu, sarana prasarana yang kurang memadai, pembiayaan yang kurang dan faktor dari dalam diri guru itu sendiri yang enggan mengembangkan potensinya. Kualifikasi dan latar belakang pendidikan tidak sesuai dengan bidang tugas. Masih ada beberapa guru mengajarkan mata pelajaran yang tidak sesuai dengan kualifikasi dan latar belakang pendidikan yang dimiliki." 21

Jawaban yang di uraikan oleh informan di atas juga menjelaskan tentang kendala-kendala dalam menunjang profesionalisme guru di Madrasah Tsanawiyah NW 02 Kembang Kerang yaitu kendala yang terjadi seperti kualifikasi dan latar belakang pendidikan tidak sesuai dengan bidang tugas. Masih ada beberapa guru mengajarkan mata pelajaran yang tidak sesuai dengan kualifikasi dan latar belakang pendidikan yang dimiliki.

Hasil wawancara peneliti dengan Staf Tata Usaha mengenai kendalakendala dalam menunjang profesionalisme guru di Madrasah Tsanawiyah NW 02 Kembang Kerang beliau memberi jawaban sebagai berikut:

${ }^{21}$ Hasil wawancara dengan wakil Kepala Madrasah I (Bidang Kurikulum) (Sahabuddin, S.Pd.I). Tanggal 13 Mei 2020 pukul 09.00 WITA. 
“Kendala-kendala yang terjadi yaitu berkenaan dengan sarana prasarana yang kurang memadai, tidak memiliki kompetensi yang diperlukan sesuai bidang tugas. Masih ada beberapa guru mengajarkan mata pelajaran yang tidak sesuai dengan kualifikasi dan latar belakang pendidikan yang dimiliki. Kesempatan guru yang sangat terbatas dalam mengembangkan kemampuannya." 22

Jawaban yang di uraikan oleh informan di atas juga menjelaskan tentang kendala-kendala dalam menunjang profesionalisme guru di Madrasah Tsanawiyah NW 02 Kembang Kerang yaitu peningkatan dan pengembangan kemampuan profesionalisme yaitu lemahnya motivasi yang dimiliki oleh pihak guru dalam mengadakan peningkatan kemampuan profesionalannya. Lemahnya motivasi dalam meningkatkan kemampuan mereka beralasan karena sibuknya waktu dalam melakukan pengajaran dan rumah tangga. Untuk mengatasi hal tersebut, maka upaya yang dilakukan kepala sekolah adalah mendorong dan memotivasi guru untuk aktif dalam pelatihan. Dalam hal ini kepala sekolah mengadakan pendekatan dan meyakinkan pada guru tentang pentingnya sikap profesional dalam mengajar dan sikap tersebut dapat diperoleh guru melalui keaktifannya di pelatihan.

Hasil wawancara peneliti dengan guru mengenai kendala-kendala dalam menunjang profesionalisme guru di Madrasah Tsanawiyah NW 02 Kembang Kerang beliau memberikan jawaban sebagai berikut:

"Sarana prasarana yang kurang memadai, Penghasilan tidak ditentukan sesuai dengan prestasi kerja, karena terlihat bahwa guru yang berprestasi dan yang tidak berprestasi mendapatkan penghasilan yang sama, memang benar sekarang terdapat program sertifkasi. Namun program tersebut tidak memberikan peluang kepada seluruh guru. Sertifikasi hanya dapat diikuti oleh guru-guru yang ditunjuk kepala sekolah yang notabane akan berpotensi subjektif." 23

Dari hasil wawancara di atas bahwa kendala-kendala dalam menunjang profesionalisme guru yaitu: Berkenaan dengan (1) sarana prasarana yang

${ }^{22}$ Hasil wawancara dengan Staf Tata Usaha (Abdul Hafiz). Tanggal 15 Mei 2020 pukul 10.00 WITA.

${ }^{23}$ Hasil wawancara dengan Guru. Tanggal 17 Mei 2020 pukul 09.00 WITA. 
kurang memadai, (2) tidak memiliki kompetensi yang diperlukan sesuai bidang tugas, (3) Masih ada beberapa guru mengajarkan mata pelajaran yang tidak sesuai dengan kualifikasi dan latar belakang pendidikan yang dimiliki, (4) Penghasilan tidak ditentukan sesuai dengan prestasi kerja, karena terlihat bahwa guru yang berprestasi dan yang tidak berprestasi mendapatkan penghasilan yang sama, memang benar sekarang terdapat program sertifkasi. Namun, program tersebut tidak memberikan peluang kepada seluruh guru. Sertifikasi hanya dapat diikuti oleh guru-guru yang ditunjuk kepala sekolah yang notabane akan berpotensi subjektif.

Kesimpulan Kendala-Kendala Kepala Sekolah dalam Menunjang Profesionalisme Guru Berkenaan dengan sarana prasarana yang kurang memadai, tidak memiliki kompetensi yang diperlukan sesuai bidang tugas, masih ada beberapa guru mengajarkan mata pelajaran yang tidak sesuai dengan kualifikasi dan latar belakang pendidikan yang dimiliki, penghasilan tidak ditentukan sesuai dengan prestasi kerja, karena terlihat bahwa guru yang berprestasi dan yang tidak berprestasi mendapatkan penghasilan yang sama, kualitas tenaga pendidik yang belum mencapai target hingga masalah kesejahteraan guru. Masih ada beberapa guru yang kurang terpacu dan termotivasi untuk memberdayakan diri, mengembangkan profesionalitas diri atau memutakhirkan pengetahuan mereka secara terus-menerus dan berkelanjutan, kurangnya kesempatan untuk mengembangkan profesi secara berkelanjutan, banyak guru yang terjebak pada rutinitas dan kurangnya biaya untuk melanjutkan studi.

Hal itu terindikasi dengan minimnya kesempatan beasiswa yang diberikan kepada guru dan tidak adanya program pencerdasan guru, misalnya dengan adanya tunjangan buku referensi dan pelatihan berkala. 


\section{Kesimpulan}

Berdasarkan hasil penelitian dan pembahasan mengenai upaya kepala sekolah dalam menunjang profesionalisme guru di Madrasah Tsanawiyah NW 02 Kembang Kerang, dapat ditarik kesimpulan bahwa sudah berjalan dengan baik yang mana sesuai dengan program yang telah dilaksanakan kepala madrasah.

Secara terperinci, sebagai kesimpulan dari upaya kepala sekolah dalam menunjang profesionalisme guru di Madrasah Tsanawiyah NW 02 Kembang Kerang adalah sebagai berikut:

1. Upaya kepala sekolah dalam menunjang profesionalisme guru di Madrasah Tsanawiyah NW 02 Kembang Kerang adalah Memberdayakan kompetensi yang dimiliki oleh guru, KKG, mengadakan pelatihan, yang mana pelatihan ini merupakan salah satu teknik pembinaan untuk menambah wawasan/ pengetahuan guru- guru dan memberikan kesempatan kepada guru-guru untuk meningkatkan pengetahuan dan keterampilannya dengan belajar ke jenjang pendidikan yang lebih tinggi. Kegiatan pelatihan (Diklat), perlu dilaksanakan oleh guru dengan diikuti usaha tindak lanjut untuk menerapkan hasil-hasil pelatihan.

2. Langkah-langkah kepala sekolah dalam menunjang profesionalisme guru di Madrasah Tsanawiyah NW 02 Kembang Kerang adalah Memberikan pengawasan dan bimbingan serta bantuan kepada guru, Menyediakan media serta kelengkapan pusat sumber belajar, bekerjasama untuk mengembangkan model pembelajaran, berusaha membina kerjasama baik dengan para guru, dan staf pegawai, meningkatkan kedisiplinan guru-guru termasuk untuk guru berpartsipasi dalam setiap kegiatan sekolah, pemberian penghargaan terhadap guru maupun pegawai yang berprestasi, memberikan kemudahan kepada guru dalam proses pengajuan kenaikan pangkatnya sesuai dengan peraturan yang berlaku, membuat kebijakan sekolah dalam pembagian tugas guru, baik beban tugas mengajar, beban administrasi guru 
maupun beban tugas tambahan lainnya harus disesuaikan kemampuan guru itu sendiri.

3. Berkenaan dengan kendala-kendala kepala sekolah dalam menunjang profesionalisme guru di Madrasah Tsanawiyah NW 02 Kembang Kerang adalah sarana prasarana yang kurang memadai, tidak memiliki kompetensi yang diperlukan sesuai bidang tugas. Masih ada beberapa guru mengajarkan mata pelajaran yang tidak sesuai dengan kualifikasi dan latar belakang pendidikan yang dimiliki. Penghasilan tidak ditentukan sesuai dengan prestasi kerja, karena terlihat bahwa guru yang berprestasi dan yang tidak berprestasi mendapatkan penghasilan yang sama, memang benar sekarang terdapat program sertifkasi. Namun, program tersebut tidak memberikan peluang kepada seluruh guru. Sertifikasi hanya dapat diikuti oleh guru-guru yang ditunjuk kepala sekolah yang notabane akan berpotensi subjektif.

\section{Daftar Refrensi}

Agustinus, H. Kepemimpinan Pendidikan di Era Globalisasi. (Yogyakarta : Pustaka Pelajar. 2014).

Aminatul, Z. Membangun Kualitas Pembelajaran Melalui Dimensi Profesionalisme Guru. (Bandung: Yrama Widya. 2015).

Fuad, I. Dasar-Dasar Pendidikan. (Jakarta: PT Rineka Cipta, 2003).

Hamni, F, N. Urgensi Profesionalisme Guru di Pendidikan Sekolah Dasar" Institut Agama Islam Negeri Padang, Vol.1, No.01, 2017.

Kompri. Standardisasi Kompetensi Kepala Sekolah. (Jakarta: Kencana. 2017).

Mesiono, Inovasi Pendidikan. (Medan: Perdana Publishing, 2012).

Muhammad, K Manajemen Pendidikan. (Yogyakarta: CV Budi Utama. 2017).

Mudlofir. Pendidikan Profesional. (Jakarta: PT Raja Grofindo. 2015).

Tobroni. Pendidikan Islam. (Jakarta: Mitra Wacana Media, 2015).

Yusutria. Profesinalisme Guru Dalam Meningkatkan Kualitas Sumber Daya Manusia" STKIP PGRI Sumatera Barat, Vol 2, No. 1, 2017. 